\title{
The pH Optimum of Tissue ATP-ases
}

\author{
*Kimiaki Nakamoto and Magojiro Maekawa \\ The 3rd Division, Department of Internal Medicine, Faculty of \\ Medicine, Kyoto University, Kyoto
}

\section{Introduction}

Recently, the specificity of histochemical demonstration of ATP-ase was investigated by many workers ${ }^{1-10}$. As a result, boundless uncertainties in the histochemical demonstration of ATP-ase were more distinctly delineated. However, it was by the use of acid ATP-ase medium, ${ }^{,, 10)}$ which enabled histochemical demonstration of cytoplasmic or mitochondrial ATP-ase, that most of the uncertainties which had been common to all of them were elucidated.

It is generally accepted that adenosine triphosphate (ATP) is a universal constituent of the organism, and with its terminal high-energy phosphate radical, it plays a part of fundamental importance in biological exchanges of energy. Therefore, it seems likely that every tissue component can utilize ATP at a certain $\mathrm{pH}$ optimum which is specific to each tissue component, specific to the coupled enzyme-catalyzed reactions in complex biochemical systems taking place in different fashions in each tissue component. However, in spite of biochemically substantiated presence of ATP-ase in the nucleus, ${ }^{11,12}$ ) ATP-dephosphorylating activity of the nucleus was low in the substrate mixtures of both acid and alkaline $\mathrm{pH}$ employed. Besides there were some tissue components which showed neither acid nor alkaline ATP-ase activity.

The present study was designed to investigate the presence of ATP-dephosphorylating enzyme (ATP-ase), of which the pH optimum is other than $\mathrm{pH} 5$ or $\mathrm{pH} 9$.

\section{Materials and Methods}

The animals used were albino rats and rabbits, and the sections employed were paraffin sections. For a detailed description of preparing paraffin sections and incubating media, readers are referred to Maekawa et al. ${ }^{\text {) }}$ or Nakamoto. ${ }^{10}$ In this paper, only the characters and compositions of incubating media of various $\mathrm{pH}$ with different $\mathrm{PO}_{4}$-binding cations, which is one of the subjects of this investigation, will be given in detail.

As is well known, in the histochemistry of dephosphorylating enzymes with lead phosphate or calcium phosphate method, one $\mathrm{PO}_{4}$-binding cation cannot be employed in all the media of $\mathrm{pH} 3$ to $\mathrm{pH} \mathrm{11}$, because quantitative precipitation of lead phosphate or lead calcium occurs only in a certain limited $\mathrm{pH}$ range.

*Present address : Department of Internal Medicine, Owase Municipal Hospital, Owase-shi, Mie-ken. 
The compositions of incubating media firstly employed were shown in Table 1 (a). As shown in Table 1 (b), the turbidity of these incubating media differed markedly depending upon the $\mathrm{pH}$ of the media. It increased with increasing acidity in $\mathrm{Pb}$-containing media, and with increasing alkalinity in Ca-containig media. This difference in the degree of turbidity apparently indicates the difference in the final, actual concentrations of effective ATP and $\mathrm{PO}_{4}$-binding cations. ${ }^{105}$ In order to minimize this difference in the final concentrations of ATP and $\mathrm{PO}_{4}$-binding cations, both $\mathrm{Pb}$ and $\mathrm{Ca}$, each in $1 / 2$ of the above dose, were employed together as $\mathrm{PO}_{4}$-binding cations at every $\mathrm{pH}$ as shown in Table 2 (a). Table 2 (b) indicates the turbidity of this series of incubating media of different $\mathrm{pH}$, which was nearly the same at every $\mathrm{pH}$. However, as shown in Table $3, \mathrm{Ca}$ in the medium of $\mathrm{pH} 5.0$ exerted a marked inhibiton, $\mathrm{Ca}$ in the medium of $\mathrm{pH} 7.0$ a marked activation, and $\mathrm{Pb}$ in the medium of pH 9.0 almost no effect on ATP-ase activity. Namely, both of these two series of incubating media were found to be inadequate for the investigation of the dependency of tissue ATP-ase upon the $\mathrm{pH}$ of the media. However, as

Table 1 (a) Compositions of Incubating Media with One $\mathrm{PO}_{4}$-binding Cation

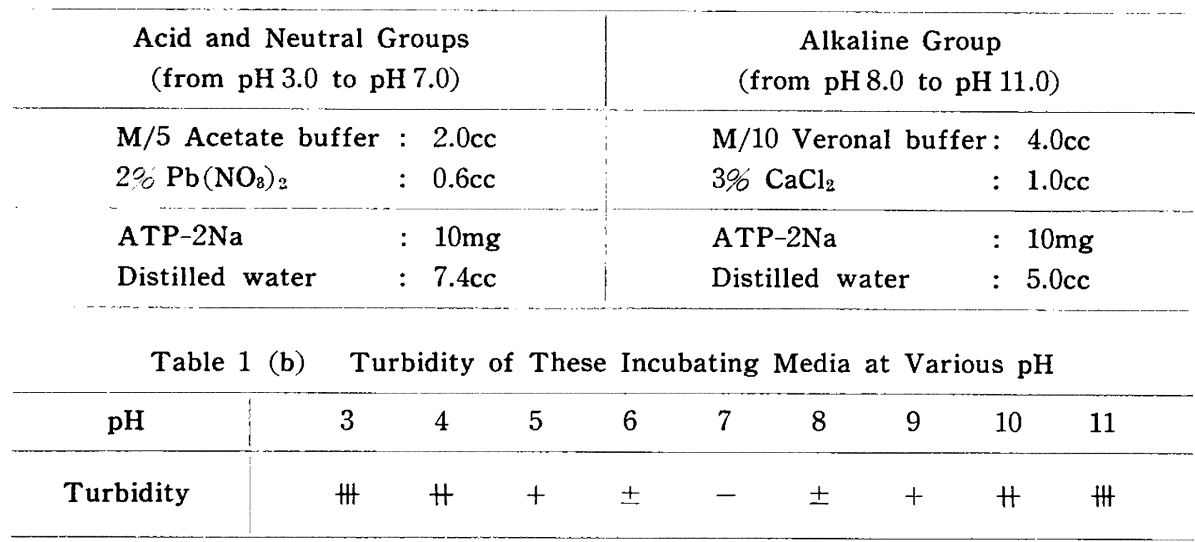

Table 2 (a) Compositions of Incubating Media with Two $\mathrm{PO}_{4}$-binding Cations

\begin{tabular}{|c|c|c|c|c|}
\hline $\begin{array}{c}\text { Acid Group } \\
\text { (from } \mathrm{pH} 3.0 \text { to } \mathrm{pH} 6.0 \text { ) }\end{array}$ & \multicolumn{2}{|c|}{$\begin{array}{c}\text { Neutral Group } \\
\text { (from } \mathrm{pH} 6.0 \text { to } \mathrm{pH} 8.0 \text { ) }\end{array}$} & \multicolumn{2}{|c|}{$\begin{array}{l}\text { Alkaline Group } \\
\text { (from } \mathrm{pH} 8.0 \text { to } \mathrm{pH} 11.0 \text { ) }\end{array}$} \\
\hline $\mathrm{M} / 5$ Acetate buf. : $2.0 \mathrm{cc}$ & M/5 Tris buffer & $: 2.0 \mathrm{cc}$ & M/10 Veronal & $: 4.0 \mathrm{cc}$ \\
\hline $2 \% \mathrm{~Pb}\left(\mathrm{NO}_{3}\right)_{2} \quad: 0.3 \mathrm{cc}$ & $2 \% \mathrm{~Pb}\left(\mathrm{NO}_{3}\right)_{2}$ & $: 0.3 \mathrm{cc}$ & $20^{\circ} \mathrm{Pb}\left(\mathrm{NO}_{3}\right)_{2}$ & $: 0.3 \mathrm{cc}$ \\
\hline $3 \% \mathrm{CaCl}_{2}$ & $3 \% \mathrm{CaCl}_{2}$ & $: 0.5 c c$ & $3 \% \mathrm{CaCl}_{2}$ & : $0.5 \mathrm{cc}$ \\
\hline ATP-2Na & ATP-2Na & : $10 \mathrm{mg}$ & ATP-2Na & : $10 \mathrm{mg}$ \\
\hline Distilled water & Distilled water & $: 7.2 \mathrm{cc}$ & Distilled water & $: 5.2 \mathrm{cc}$ \\
\hline
\end{tabular}

Table 2 (b) Turbidity of These Incubating Media at Various $\mathrm{pH}$

\begin{tabular}{|c|c|c|c|c|c|c|c|c|c|}
\hline $\mathrm{pH}$ & 3 & 4 & 5 & 6 & 7 & 8 & 9 & 10 & 11 \\
\hline Turbidity & + & + & + & + & + & + & + & + & + \\
\hline
\end{tabular}


shown in Table 3, the intensity of ATP dephosphorylation was highest in the media containing $\mathrm{Pb}$ alone between $\mathrm{pH} 4.0$ and $\mathrm{pH} 6.0$, in the media containing $\mathrm{Pb}$ and $\mathrm{Ca}$ between $\mathrm{pH} 6.0$ and $\mathrm{pH} 8.0$, and in the media containig $\mathrm{Ca}$ alone between $\mathrm{pH} 8.0$ and $\mathrm{pH} 10.0$. And if the media of $\mathrm{pH} 4$ to $\mathrm{pH} 10$ was divided into 3 groups, acid, neutral and alkaline, the difference in the final concentrations of ATP and $\mathrm{PO}_{4}$-binding cations can be minimized in each group which consists of the same $\mathrm{PO}_{4}$-binding cation or cations and ATP of nearly the same concentration. The compositions of the media finally employed were shown in Table 4. Thus, at $\mathrm{pH} 6$ and $\mathrm{pH} 8$, ATP-ase was demonstrated with 2 or 3 media containing different $\mathrm{PO}_{4}$-binding cations in order to see the difference in the effect of each $\mathrm{PO}_{4}$-binding cation on tissue ATP-ases.

\section{Results}

I. Effects of $\mathrm{Pb}$ and $\mathrm{Ca}$ upon different tissue ATP-ases at the same $\mathrm{pH}$. As shown in Table 5, Ca markedly inhibited cytoplasmic ATP-ase of rat

Table 3 Intensity of Reactions in the Media of the Same $\mathrm{pH}$ with Different $\mathrm{PO}_{4}$-binding Cations

\begin{tabular}{|c|c|c|c|c|c|c|c|c|c|}
\hline $\mathrm{pH}$ & 3 & 4 & 5 & 6 & 7 & 8 & 9 & 10 & 11 \\
\hline $\mathrm{Pb}^{++}$ & \pm & H & m & H & + & + & & & \\
\hline $\mathrm{Pb}^{++}+\mathrm{Ca}^{++}$ & - & \pm & \pm & H & 世 & $H$ & 册 & 冊 & 曲 \\
\hline $\mathrm{Ca}^{++}$ & & & & & & H & 無 & 册 & 册 \\
\hline
\end{tabular}

Table 4 Compositions of Incubating Media Finally Employed

\begin{tabular}{|c|c|c|c|c|c|}
\hline \multirow{2}{*}{\multicolumn{2}{|c|}{$\begin{array}{l}\text { Acid Group } \\
\text { (from } \mathrm{pH} 4.0 \text { to } \mathrm{pH} 6.0 \text { ) } \\
\text { M/5 Acetate buf. }: 2.0 \mathrm{cc}\end{array}$}} & \multicolumn{2}{|c|}{$\begin{array}{c}\text { Neutral Group } \\
\text { (from } \mathrm{pH} 6.0 \text { to } \mathrm{pH} 8.0 \text { ) }\end{array}$} & \multicolumn{2}{|c|}{$\begin{array}{c}\text { Alkaline Group } \\
\text { (from } \mathrm{pH} 8.0 \text { to } \mathrm{pH} 10.0 \text { ) }\end{array}$} \\
\hline & & M/5 Tris buf. & $: 2.0 \mathrm{cc}$ & \multirow{2}{*}{\multicolumn{2}{|c|}{$\mathrm{M} / 10$ Veronal buf.: $4.0 \mathrm{cc}$}} \\
\hline \multirow[t]{2}{*}{$2 \% \mathrm{~Pb}\left(\mathrm{NO}_{3}\right)_{2}$} & $: 0.6 \mathrm{cc}$ & $20_{0} \mathrm{~Pb}\left(\mathrm{NO}_{3}\right)_{2}$ & $: 0.3 \mathrm{cc}$ & & \\
\hline & & $3 \% \mathrm{CaCl}_{2}$ & $: 0.5 \mathrm{cc}$ & $30_{0} \mathrm{CaCl}_{2}$ & $: 1.0 \mathrm{cc}$ \\
\hline ATP-2Na & $: 10 \mathrm{mg}$ & ATP- $2 \mathrm{Na}$ & $: 10 \mathrm{mg}$ & ATP-2Na & $: 10 \mathrm{mg}$ \\
\hline Distilled water & $: 7.4 \mathrm{cc}$ & Distilled water & $: 7.2 \mathrm{cc}$ & Distilled water & $: 5.0 \mathrm{cc}$ \\
\hline
\end{tabular}

To see the effect of $\mathrm{Mg}, 0.1 \mathrm{cc}$ of $1 \% \mathrm{MgCl}_{2}$ was added to the above respectively.

Table 5 Rat Liver ATP-ase at $\mathrm{pH} 5.0$ in the Media with Different Catons

\begin{tabular}{l|cccc}
\hline \multicolumn{1}{c}{ Cations } & $\mathrm{Pb}$ & $\mathrm{Pb}+\mathrm{Mg}$ & $\mathrm{Pb}+\mathrm{Ca}$ \\
\hline Hepatic Cells & $\mathrm{W}$ & $\mathrm{W}$ & \pm \\
Bile Canaliculi & - & - & - \\
\hline
\end{tabular}

Table 6 Rat Liver ATP-ase at pH 7.0 in the Media with Different Cations

\begin{tabular}{l|cccc}
\multicolumn{1}{c|}{ Cations } & $\mathrm{Pb}$ & $\mathrm{Pb}+\mathrm{Mg}$ & $\mathrm{Pb}+\mathrm{Ca}$ \\
\hline Hepatic Cells & - & - & - \\
Bile Canaliculi & - & $\mathrm{H}$ & H \\
\hline
\end{tabular}


Table 7 Ret Heart ATP-ase at $\mathrm{pH} 8.0$ in the Media with Different Cations

\begin{tabular}{l|ccc}
\multicolumn{1}{c|}{ Cations } & $\mathrm{Pb}$ & $\mathrm{Pb}+\mathrm{Ca}$ & $\mathrm{Ca}$ \\
\hline Cardiac Muscles & $\mathrm{H}$ & - & H thrm \\
Capillaries & - & - & H \\
\hline
\end{tabular}

Table 8 Rat Liver ATP-ase at Var!ous pH

\begin{tabular}{l|ccccccc}
\multicolumn{1}{c}{$\mathbf{p H}$} & 4 & 5 & 6 & 7 & 8 & 9 & 10 \\
\hline Hepatic Cells & +4 & H & H & \pm & - & - & \pm \\
Bile Canaliculi & - & - & $H$ & $\#$ & \pm & $\#$ & $\#$ \\
Endothelia of Central Veins & - & - & - & \pm & $\#$ & \pm & -
\end{tabular}

Table 9 Rat Pancreas ATP-ase at Various pH

\begin{tabular}{|c|c|c|c|c|c|c|c|}
\hline $\mathrm{pH}$ & 4 & 5 & 6 & 7 & 8 & 9 & 10 \\
\hline Acinar Cells & + & 册 & + & \pm & - & - & \pm \\
\hline Islets Cells & - & \pm & - & + & H & 册 & H \\
\hline Intralobular Ducts & - & - & - & \# & 世 & + & \pm \\
\hline Capillaries & - & - & - & - & \pm & 册 & H \\
\hline
\end{tabular}

Table 10 Rat Kidney ATP-ase at Various pH

\begin{tabular}{|c|c|c|c|c|c|c|c|}
\hline $\mathrm{pH}$ & 4 & 5 & 6 & 7 & 8 & 9 & 10 \\
\hline Glomeruli & - & \pm & - & - & + & H & $H$ \\
\hline $\begin{array}{l}\text { Proximal } \\
\text { Convolution }\end{array}$ & - & - & + & H & 世 & 册 & 冊 \\
\hline Convolution $\{$ Cytoplasm & H & 世 & $H$ & + & \pm & \pm & \pm \\
\hline Distal Convolution : Cytoplasm & + & $H$ & + & \pm & - & - & - \\
\hline Collecting Tubules: Cytoplasm & + & H & + & \pm & - & - & - \\
\hline Capillaries & - & - & - & - & + & $H$ & $H$ \\
\hline
\end{tabular}

Table 11 Rabbit Brain ATP-ase at Various $\mathrm{pH}$

$$
\begin{array}{l|lllllll}
\mathrm{pH} & 4 & 5 & 6 & 7 & 8 & 9 & 10
\end{array}
$$

Nuclei of Nerve Cells $\quad-\quad-\quad \pm \quad+\#+4+$

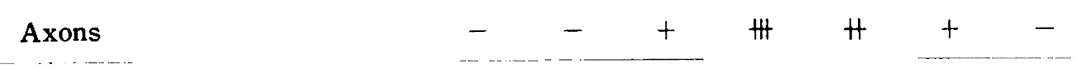

Table 12 Rabbit Adrenal ATP-ase at Various $\mathrm{pH}$

\begin{tabular}{|c|c|c|c|c|c|c|c|}
\hline $\mathrm{pH}$ & 4 & 5 & 6 & 7 & 8 & 9 & 10 \\
\hline Cortical Cells & $H$ & m & H & - & - & - & - \\
\hline Nuclei of Cortical Cells & - & - & + & H & 册 & 册 & \pm \\
\hline Capillary Sinuses & - & - & - & - & - & + & 世 \\
\hline Erythrocytes & 册 & 世 & H & \pm & - & - & - \\
\hline
\end{tabular}


liver cell at $\mathrm{pH} 5$. While, $\mathrm{Pb}$ markedly inhibited bile canaliculus $\mathrm{ATP}$-ase at pH 7.0 and capillary ATP-ase of rat heart at pH 8.0 as shown in Tables 6 and 7.

II. Effect of the $\mathrm{pH}$ of incubating media upon ATP-ases of various tissue components.

As shown in Tables $8,9,10,11$, and 12 , each tissue component had its own $\mathrm{pH}$ optimum specific to it. Histochemical scores at $\mathrm{pH} 6.0$ and 8.0 given in the tables were those obtained in the media of the neutral group.

a) Rat liver

The cytoplasm of the liver cells showed the highest activity at $\mathrm{pH} 5.0$, the bile canaliculus at $\mathrm{pH} 7.0$ without zonal difference in the hepatic lobule, the stellate cells and endothelial cells of the central veins at $\mathrm{pH} 8.0$ and again the bile canaliculus at $\mathrm{pH} 9.0$ with a stronger reaction in the periportal area. The nucleus showed the highest activity at $\mathrm{pH} 7.0$.

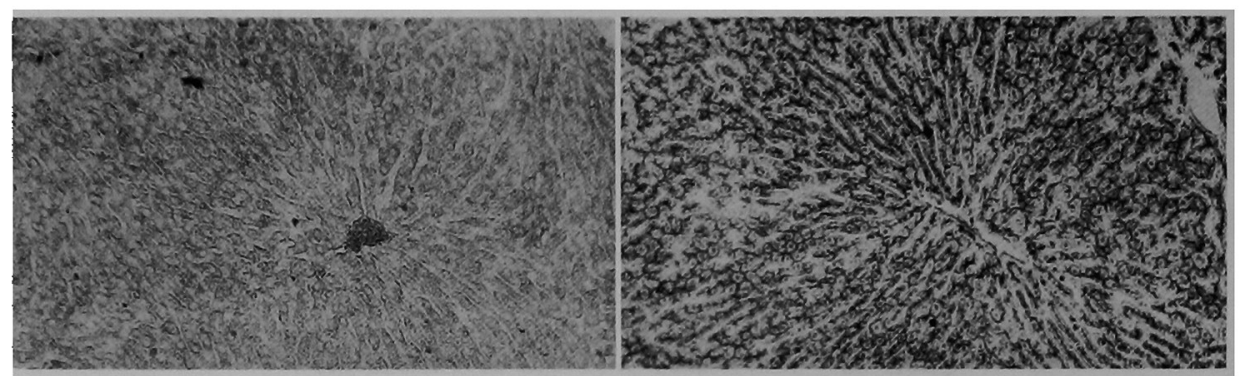

Fig. 1 rat liver, $\mathrm{pH} 4.0, \mathrm{~Pb}$ alone, $180 \mathrm{~min}, \times 100$.
Fig. 4 rat liver, $\mathrm{pH} 7.0, \mathrm{~Pb} \& \mathrm{Ca}$, $150 \mathrm{~min}, \times 100$.

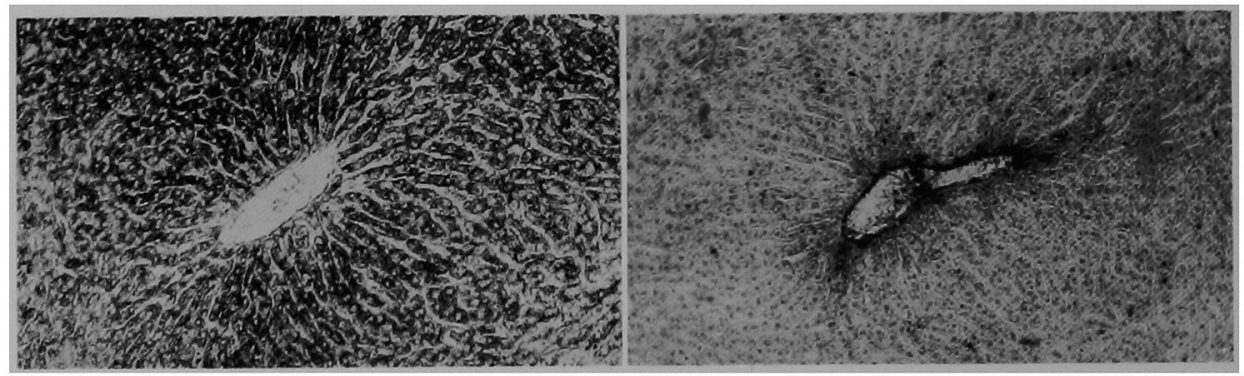

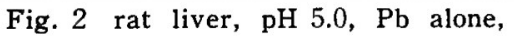
$180 \mathrm{~min}, \times 100$.
Fig. 5 rat liver, $\mathrm{pH} 8.0, \mathrm{~Pb} \& \mathrm{Ca}$, $120 \mathrm{~min}, \times 100$.

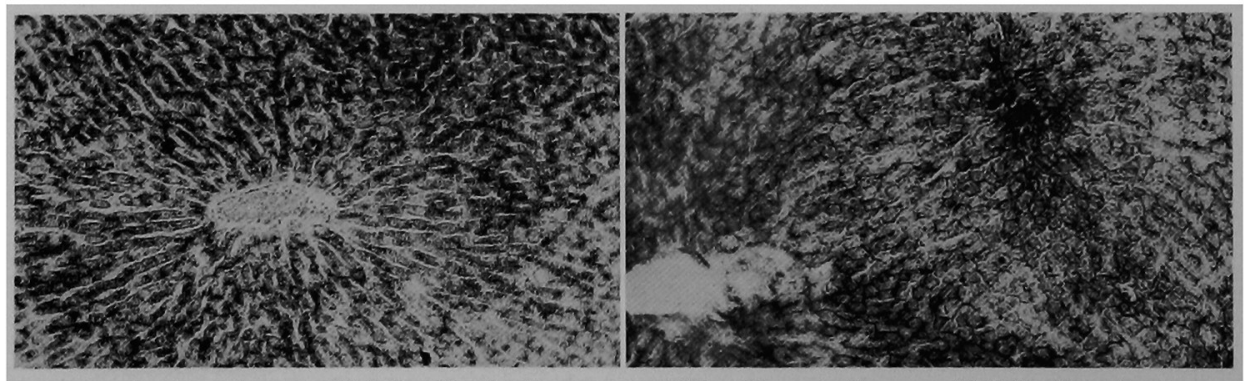

Fig. 3 rat liver, $\mathrm{pH} 6.0, \mathrm{~Pb} \& \mathrm{Ca}$, $150 \mathrm{~min}, \times 100$.
Fig. 6 rat liver, pH 9.0, Ca alone, $120 \mathrm{~min}, \times 100$. 
b) Rat pancreas

As shown in Table 9, the cytoplasm of acinar cells showed the highest activity at $\mathrm{pH} 5.0$; the nuclei at $\mathrm{pH} 7.0$, the intralobular ducts at $\mathrm{pH} 8.0$ and the capillaries and islet cells at $\mathrm{pH} 9.0$.

c) Rat kidney

The cytoplasm of epithelial cells of the proximal and distal convoluted tubules, thick limbs of Henle and collecting tubules showed the highest activity at $\mathrm{pH} 5.0$, the nuclei at $\mathrm{pH} 7.0$ and the brush borders of the proximal convoluted tubules at $\mathrm{pH} 9.0$.

d) Rabbit brain

As shown in Table 11, the axons and nuclei of nerve cells showed the highest activity at $\mathrm{pH} 7.0$, the neuroglia at $\mathrm{pH} 5.0$ or at $\mathrm{pH} 9.0$ depending on the layers at which it located, and the capillaries at $\mathrm{pH} 9.0$.

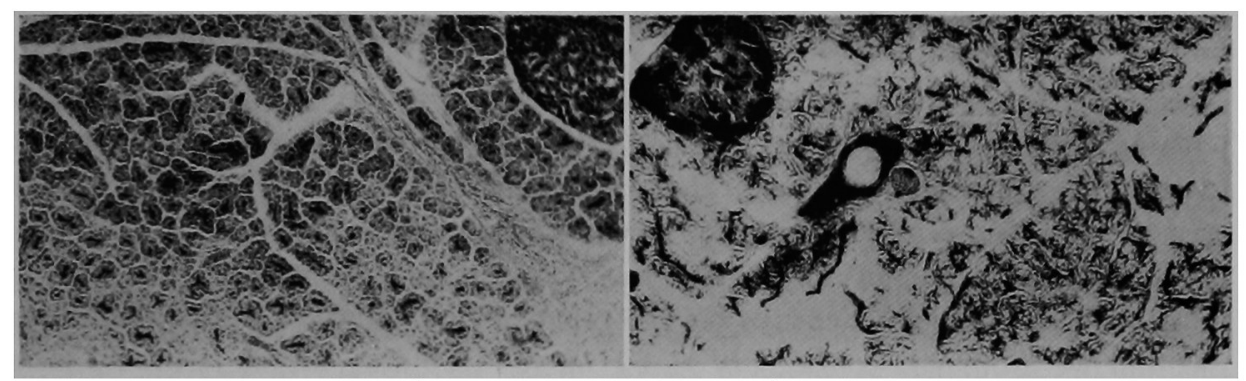

Fig. 7 rat pancreas, $\mathrm{pH} 8.0, \mathrm{~Pb} \& \mathrm{Ca}$ $120 \mathrm{~min} \times 100$.

Fig. 8 rat pancreas, $\mathrm{pH} 9.0, \mathrm{Ca}$ alone, $120 \mathrm{~min}, \quad \times 100$.

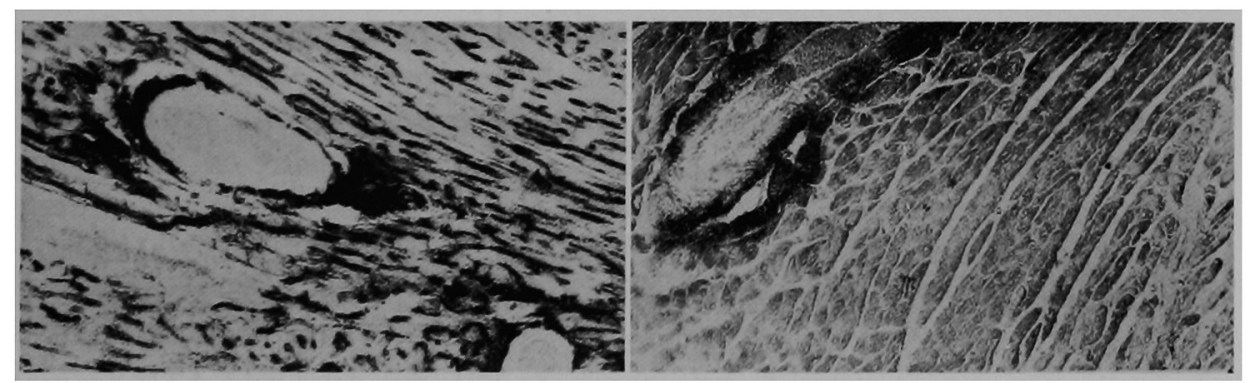

Fig. 9 rat heart, $\mathrm{pH} 8.0, \mathrm{Ca}$ alone, $120 \mathrm{~min}, \times 100$.

Fig. 10 rat heart, $\mathrm{pH} 8.0, \mathrm{~Pb}$ alone, $120 \mathrm{~min}, \times 100$.

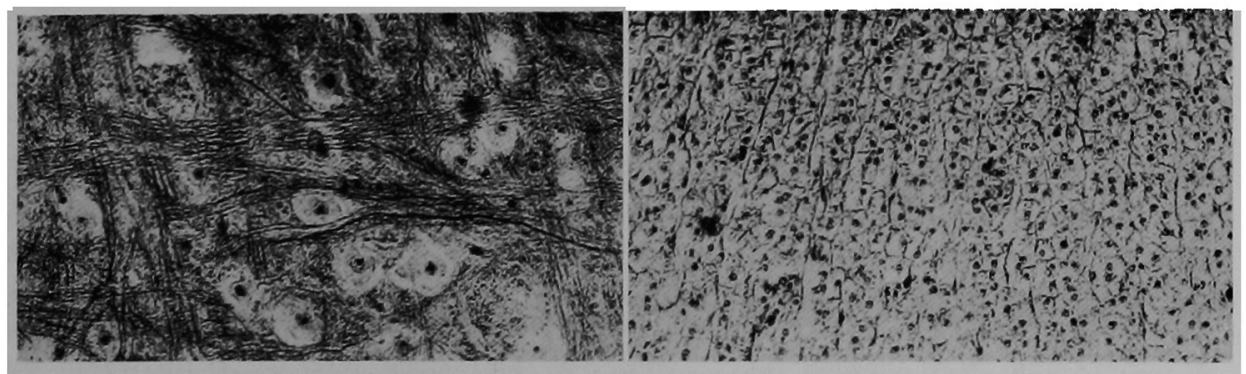

Fig. 11 rabbit brain, $\mathrm{pH} 7.0, \mathrm{~Pb} \&$ $\mathrm{Mg}, \times 200$.
Fig. 12 rabbit adrenal gland, $\mathrm{pH} 7.0$, $\mathrm{Pb} \& \mathrm{Mg}, \times 200$. 
e) Rabbit adrenal gland

The cytoplasm of cortical cells and erythrocyte showed the highest activity at $\mathrm{pH} 5.0$, the nucleus of cortical cells at $\mathrm{pH} 7.0$ and the capillary sinuses at $\mathrm{pH}$ 9.0. The behaviour of the nucleus was the same in every organ and in both rabbits and albino rats. The intensity of nuclear staining was greater in nondeparaffinized sections than in deparaffinized sections.

\section{Discussion}

I. Mg-Activated and Ca-inhibited ATP-ase in the cytoplasm

In 1948 Kielley and Meyerhof ${ }^{18)}$ reported the presence of a new ATP-ase in the muscle which is activated by $\mathrm{Mg}$ and inhibited strongly by $\mathrm{Ca}$. The $\mathrm{pH}-$ activity curve appeared in their report shows that the $\mathrm{pH}$ optimum of this ATPase is present between $\mathrm{pH} 6.0$ and 7.0, and activity is nearly zero at $\mathrm{pH} 9.5$. In 1953 Kielly and Kielly reported an ATP-dephosphorylating enzyme in the liver mitochondria which is also $\mathrm{Mg}$-activated and $\mathrm{Ca}$-inhibited. Observing an increase in the ATP-ase activity at $\mathrm{pH}$ values acid to the $\mathrm{pH}$ optimum ( $\mathrm{pH} \mathrm{8.5)}$ with an increase in $\mathrm{Mg}$ concentration, they stated that $\mathrm{Mg}$ functions in the hydrolytic reaction by increasing the negative charge on the terminal phosphate of ATP forming a ATP-Mg complex which may be a true substrate of ATPase. Since, as is generally accepted, enzyme proteins are multivalent dipolar ions, their dissociaition depends on the $\mathrm{pH}$ of the medium. The acid ATP-ase medium we employed contains $0.003 \mathrm{M} \mathrm{Pb}$ as $\mathrm{PO}_{4}$-binding cation. This $\mathrm{Pb}$ may act as $\mathrm{Mg}$ in Kielley and Kielley's biochemical medium forming enzyme-substrate compounds by way of ATP-Pb complex. In 1952 Novikoff et al. ${ }^{15)}$ reported that the degree of stimulation of ATP dephosphorylation by $\mathrm{Mg}$ and $\mathrm{Ca}$ was strikingly different in the nuclear and mitochondrial fractions: the two ions were equally effective stimulators for the nuclear fraction, with the mitochondrial fraction, however, $\mathrm{Mg}$ stimulated but $\mathrm{Ca}$ did not. Basing on these observations, they stated that it is possible that the nuclei possess an entirely different enzyme or enzymes from the mitochondrial ATP-ase. Nakamoto ${ }^{10}$ ) found histochemically that $\mathrm{Mg}$ activates cytoplasmic acid ATP-ase and is nearly indifferent to alkaline ATP-ase.

In the present experiment, cytoplasmic or mitochondrial acid ATP-ase was strongly inhibited by $\mathrm{Ca}$, and the nuclei and axons reacted more strongly in the medium containing $\mathrm{Pb}$ and $\mathrm{Mg}$ at $\mathrm{pH} 7.0$ and in the medium containing $\mathrm{Pb}$ and $\mathrm{Ca}$ at $\mathrm{pH} 8.0$ than in the medium containing $\mathrm{Pb}$ alone, respectively.

III. Degree of ATP dephosphorylation

Novikoff et al. ${ }^{15}$ ) stated that during periods of incubation in an enzymelimited system, at a $\mathrm{Mg}$ concentration optimal for ATP dephosphorylation, very little $A-5^{\prime}-P$ dephosphorylation occurs, and alkaline phosphatase, although it splits ATP even at neutral $\mathrm{pH}$, is of little quantitative significance since it occurs in very small quantities in normal rat liver. They further stated that although there are many enzyme-catalyzed reactions participated in by ATP and its derivatives, it would appear that under conditions similar to those of Dubois and Potter the rate of orthophosphate liberation for rat liver homogenate 
and its mitochondrial fraction is chiefly a measure of ATP-ase, and the high level of adenylate kinase activity makes it likely that any ADP formed by ATP-ase action would quickly be converted to A-5'-P and ATP. While, Kielley and Kielley ${ }^{14)}$ stated that the apparent apyrase activity of mitochondria may be the combined activity of a true ATP-ase and the adenylate kinase. Employing the sections in which acid phosphatase was inactivated and acid ATP-ase remained active, and the sections in which alkaline phosphatase remained active and alkaline ATP-ase was inactivated by heated water pretreatment, we previously demonstrated that with short incubation the reaction products in the acid ATP-ase medium is due to acid ATP-ase activity and those in the alkaline ATP-ase medium due to alkaline ATP-ase, although ATP is dephosphorylated in small quantities by alkaline phosphatase in the alkaline ATP-ase medium with a longer incubation. For a detailed description of the procedures of this heated water pretreatment, readers are referred to Maekawa et $\mathrm{al}^{9)}$. or Nakamoto ${ }^{10}$.

\section{Summary}

The $\mathrm{pH}$ optimum of tissue ATP-ases was investigated by the use of incubating media of various $\mathrm{pH}$ containing $\mathrm{Pb}$ and/or $\mathrm{Ca}$ as $\mathrm{PO}_{4}$-binding cations. 1) $\mathrm{Ca}$ inhibited cytoplasmic $\mathrm{ATP}$-ase at $\mathrm{pH} 5.0$, and $\mathrm{Pb}$ inhibited capillary and bile canaliculus ATP-ases at pH 7.0. 2) The cytoplasmic ATP-ase showed the highest activity at $\mathrm{pH} 5.0$, the nuclei, axons and bile canaliculi at $\mathrm{pH} 7.0$, the intralobular pancreatic ducts and endothelial cells of the cells of the central veins of the liver at 8.0 , and the capillaries, periportal bile canaliculi, brush brders of the proximal convoluted tubules and sinusoid walls of the adrenal gland at $\mathrm{pH} 9.0$.

\section{Acknowledgment}

The authors gratefully acknowledge their indebtedness to Professor $\mathrm{H}$. Takamatsu and to the staffs of his laboratory for the privilege given to one of the authors in his laboratory.

1) Takeuchi, T. and Okawara, T. : Igaku to Seibutsugaku (Medicine \& Biology) 26:224, 1953 (Jap. text) 2) Takeuchi, T. and Okawara, T.: Igaku to Seibutsugaku (Medicine \& Biology) $28: 123,1953$ (Jap. text) $\quad$ 3) Novikoff, A. B., Hansman, D. H. and Pdber, E. : J. Histochem. \& Cytochem. 6: 61, 1958. 4) Padykula, H. A. and Herman, E. : J. Histochem. \& Cytochm. $3: 161,1955 . \quad 5)$ Pabykula, H. A. and Herman, E. : J. Histochem. \& Cytocem. $3: 161,170,1955 . \quad 6)$ Freiman, D. G. and Kaplan, N. : J. Histochem. \& Cyto. chem. $7: 319,1959$. 7) Freiman, D. G. and Kaplan, N.: J. Histochem. \& Cytochem. 8 : 159, 1960. 8) Wachstein, M. and Meisel, E. : Am. J. Clin. Path. $27: 13,1957 . \quad 9$ ) Maekawa, M., Motomura, S., Nakamoto, K. and Ikeda, S. : Pro. Jap. Histochem. Ass. I : 110, 1961 (Eng. text) 10) Nakamoto, K, : Acta Sch. Med. Univ. Kioto Jap. 37 (3) : 414, 1961 (Eng. text) 11) Novikoff, A. B., Podber, E. and Ryan, J. : Fed. Proc. 9 : 210, 1950. 12) Inaba, A.: Jap. J. Renology 2 (4) : 654, 1960 (Eng. text) 13) Kielley, W.W. and Meyerhof, O.: J. Biol. Chem. 174: 387, 1948. 14) Kielley, W.W. and Kielley, R. K. : J. Biol. Chem. $200: 213,1953$.

15) Novikoff, A. B., Hecht, L., Podber, E., and Ryan, J. : J. Biol. Chem. 194 : 153, 1952. 
Dr. Takeuchi : Which do you mean by "ATP-ase reaction", the summerized reactions by use of ATP as substrate or the reaction for specific ATP-ase activity? This is an important matter from the stand point of histochemical specificity. The dissociation of phosphor from ATP may occur by the action of not only specific ATP-ase but of alkaline phosphatase, acid phosphatase, 5-nuleotidase and apyrase. The present study does not differentiate between the specific and nonspecific reactions.

Dr. Ogawa: It seems to me that the present stndy is incomplete to appreciate the specificity of ATP-ase.

Dr. Nagata : It is fairly difficult to estimate quantitatively histochemical reactions by means of such as the present studies.

Dr. Nakamoto: In regard to the specificity of the ATP-ase reactions, we have already investigated and reported at the first meeting of this association. We can recognize the specificity from 1) distribution, 2) resistance to water and heat, 3) influence of phenothiazine. I wish to be informed any other more appropriate method for the differentiation.

Dr. Takamatsu : I have ever had the identical doubt with those of Dr. Takeuchi and Dr. Ogawa to the works of Dr. Nakamoto, and have had the chance to observe his specimens. At the last meeting of this association, I have discussed to him as follows; "If we can sufficiently differentiate the specificity through a simple procedure such as heat treatment it may be a "powerful and excellent method." Now, I wish to repeat the same disscussion.

\title{
Techniques in Semi-Quantitative ATP-ase Histochemistry With Paraffin Setions
}

\author{
*Kimiaki Nakamoto, Magojiro Maekawa, Koichi Ogino, \\ and Shunji Motomura
}

The 3rd Division, Department of internal Medicine, Faculty

of Medicine, Kyoto University, Kyoto

\section{Introduction}

In spite of vigorous efforts to convert a qualitative histochemistry to a quantitative one, quantitative estimation of histochemical results has been much criticized because enzyme histochemistry is subjected to many uncontrollable factors in the processes. Nakamoto ${ }^{1)}$ studied various factors affecting the amount of reaction products on paraffin sections and discussed the problems in semiquantitative phosphatase histochemistry. Basing on his conclusions, semi-quantitative histochemical techniques with paraffin sections were further systematized and employed in ATP-ase histochemistry of experimental atheroma in rabbits and that of blood vessels in albino rats.

* Present address : Department of Internal Medicine, Owase Municipal Hospital, Owaseshi, Mie-ken. 